\title{
Amalgamation of PRIs and ICT: A Boon for the Downtrodden
}

\author{
Rajesh Sharma \\ Mody University of Science and \\ Technology \\ Asstt. Professor (Economics) \\ Lakshmangarh, Sikar, \\ Rajasthan, India
}

\author{
Puneet Kumar \\ Mody University of Science and \\ Technology \\ Asstt. Professor (Computer Sc.) \\ Lakshmangarh, Sikar, \\ Rajasthan, India
}

\author{
Krishna Murari \\ Mody University of Science and \\ Technology \\ Asstt. Professor (Management) \\ Lakshmangarh, Sikar, \\ Rajasthan, India
}

\begin{abstract}
One could not learn swimming without entering into the pool. Same is applicable on the success of any developmental programme. It is doubtful to eliminate the underdevelopment of rural India without the active participation of rural folk and local level administration. After the 73rd Constitutional Amendment; states have started to generate the local level participation and essential infrastructure for the socioeconomic development of rural people. As a result, these rural development programmes have also started to pick the momentum, which is an unprecedented event. Although positive effects of these programmes have been observed across the country, but their pace shall be hindered by unavoidable factors like lack of participation, lack of awareness and unavailability of information, etc. Therefore, to forfeit such types of constraints ICT can play a vital role and leads to e-democracy.
\end{abstract}

\section{Keywords}

PRIs, Rural Development, e-Panchayat, Panchayati Raj

\section{INTRODUCTION}

Increase in national income alone is not an end of all the problems unless rural development does take place [1] as majority of Indian populace lives in rural areas [2]. Therefore, in last several decades, rural development has emerged as a most prominent socio-economic issue for the policy makers in India. The political parties are also giving considerable attention to the rural development and made it as one of priority in their manifestos. Rural underdevelopment can be removed by using two dimensional approaches: First, we need to generate indigenous resources and technology to upsurge the participation of rural people; second, we need to confiscate that force which influences uniform development of all section of society. Our policy makers have also started to assert the importance of inclusive growth. To accomplish the objectives of rural development and decentralized governance, the involvement of people up to grass root level is essential in conceptualization of developmental strategies. In the present scenario Information and Communication Technology (ICT) has emerged as a tool for sensitizing as well as empowering the people. Moreover, the government of India has also initialed National e-Governance Plan (NeGP) in 2006 comprising of various Mission Mode Projects (MMPs) for strengthening largest democracy across the world [3] with the objective of disseminating various types of services like G2C (Government to Citizen), G2B (Government to
Business), G2G (Government to Government) and G2E (Government to Employee). [4]

\section{NEED OF PANCHAYATI RAJ INSTITUTIONS}

In 1951, when planning process was launched at that time population of India was 361088090 , out of that 298644381 people were residing in villages. [5] Surprisingly, $47.37 \%$ of rural people were below poverty line and top $10 \%$ of population had received about $35 \%$ of the income. [6][7] Without local level participation it was sparingly difficult to bridge such a vast income gap and it became a daunting task for the policy makers also to include this downtrodden segment of rural vicinity in the main-stream of life. Consequently, in 1952 Community Development Programme was started to encompass the rural people in economic development. Article 40 of Indian Constitution had already directed the state to organize the Gram Panchayat at village level and provide it necessary powers and functions which are essential for it to establish as a unit of self-government. [8] Later on, Balwantrai Mehta Committee (1957) in its final report also advocated the significance of three-tier structure for the implementation of various programmes and schemes at village level. This three-tier structure was named as 'Panchayati Raj'. However, recommendations of Balwantrai Mehta Committee were not followed by all the states seriously. In the mid-term appraisal of seventh five year plan it was accentuated to make the rural development programmes compatible with Panchayati Raj institutions in the following words:

"It is noticed that wherever the Panchayati Raj institutions have been actively involved, the implementation of rural development programmes has been better and the selection of beneficiaries and designing of schemes have been more satisfactory. The planning Commission has been impressing upon the states that various rural development programmes will be more realistic and meaningful if people's representatives are actively involved and associated in local level planning, design formulation and implementation of those programmes and selection of those beneficiaries in the anti-poverty and employment programmes such as IRDP, NREP, RLEGP, etc. and there is no better instrument to meet this need other than Panchayati Raj institutions." (Government of India, 1987: 16) [9]

Therefore, 73rd Constitutional Amendment was embraced to provide everlasting status to these institutions of local participations. It was projected that the new local self- 
government system would be able to transport the necessary support to the rural development programmes. The Act directs the states to give necessary powers to Panchayats for the implementation of rural development programmes. The prerequisite for the success of these rural development programmes is to have an active involvement of Panchayati Raj institutions. State governments are stipulated to provide the basic infrastructure and bureaucracy at all three levels. Even the Ministry of Panchayati Raj also actively contributes and cooperates to accomplish the aforesaid. This Ministry publishes a monthly newsletter 'Grameen Bharat' on the current status of rural development programmes which is a helpful information source for various stakeholders. [10] Now, it is the onus of state governments to follow the statute in letter and spirit.

\section{PRESENT STATUS OF RURAL DEVELOPMENT PROGRAMMES}

The Ministry of Rural Development which has further been divided in to three departments: (i) Department of Rural Development (ii) Department of Land Resources (iii) Department of Drinking Water \& Sanitation which has now been converted into separate Ministry as Ministry of Drinking Water and Sanitation (13th July, 2011); is seriously involved in eradicating poverty from rural India. The major rural development programmes which have been launched by Ministry of Rural Development in rural areas are : (i) Mahatma Gandhi National Rural Employment Guarantee Scheme (MGNREGS) (ii) National Rural Livelihoods Mission (NRLM) (iii) Indira Awaas Yojana (IAY) (iv) Pradhan Mantri Gram Sadak Yojana (PMGSY) (v) National Social Assistance Programme (NSAP) (vi) Integrated Watershed Management Programme (IWMP). And the major schemes launched by Department of Land Resources are: (i) Drought Prone Area Programme (DPAP) (ii) The Desert Development Programme (DDP) (iii) Integrated Waste Land Development Programme (IWDP) (iv) and Land Reforms. [11] To run these programmes smoothly, Ministry of Rural Development was allocated Rs. 397071.73 crore during the 11th Five Year Plan which was increased to Rs. 830613.59 crore in the 12th Five Year Plan. [12]

As a result of above allocation the reduction in poverty was witnessed to $25.7 \%$ in $2011-12$ from $50.1 \%$ in $1993-94$ on account of positive impact of rural development programmes. Further, it is evident from the table that the average annual rural poverty ratio $(2.32 \%)$ declined rapidly as compare to urban areas $(1.69 \%)$.

\begin{tabular}{|l|c|c|c|c|c|c|}
\hline \multirow{2}{*}{ Year } & \multicolumn{3}{|c|}{ Poverty Ratio (\%) } & \multicolumn{3}{|c|}{$\begin{array}{c}\text { Number of Poor } \\
\text { (million) }\end{array}$} \\
\cline { 2 - 7 } & Rural & Urban & Total & Rural & Urban & Total \\
\hline $1993-94$ & 50.1 & 31.8 & 45.3 & 328.6 & 74.5 & 403.7 \\
\hline $2004-05$ & 41.8 & 25.7 & 37.2 & 326.3 & 80.8 & 407.1 \\
\hline $2011-12$ & 25.7 & 13.7 & 21.9 & 216.5 & 52.8 & 269.3 \\
\hline $\begin{array}{l}\text { Annual } \\
\text { Average } \\
\text { Decline } \\
2004-05 \\
\text { to }\end{array}$ & 2.32 & 1.69 & 2.18 & - & - & - \\
$2011-12$ & & & & & & \\
\hline
\end{tabular}

Source: Press Note on Poverty Estimates; Government of India, Planning Commission (July 2013)
Although, the results of the various rural development programmes are overwhelming but to maintained it sustainably more efforts are required to strengthen PRIs. Therefore, the intrusion of ICT is necessary of mobilizing the people by facilitating and empowering PRIs in terms of their powers, responsibilities, level of awareness about various types of services offered by state as well as central governments etc.

\section{NEED OF ICT IN PRIS}

India comprises of millions of people which are not able to fulfill even their basic needs. In such circumstances will it be rational to inculcate the usage of ICT or adoption of electronic services with various objectives for such populace? However, it seems peculiar but to think that ICT and e-governance can't be beneficial for such a nation where a huge population is not having accessibility to basic needs for their livelihood is a paradox. But it leads towards their economic and social development. ICT involves the representation of any information in digital form along with its electronic processing, storage, retrieval and dissemination. [13] The access of ICT helps in creating sustainable economic relationships and efficient markets. Moreover, it is also helpful in eradication of poverty, improving health and other issues [14]

Globally there are various countries which are endeavoring towards rejuvenating their public administration by making it more proactive, accountable, service-oriented and transparent. This transformation requires intervention of technology in administration. And hence ICT can play significant role in advancement of public sector and its administration. Use of ICT in governance facilitates communications and enriches coordination of bureaucrats or elected representatives within different tiers of government [15][16].

\section{CASE STUDY OF E-PANCHAYAT}

This is a MMP which intends to improve quality of governance in PRIs which includes 0.235 million Gram Panchayats, 6094 Block Panchayats and 633 Zilla Panchayats. Further, it also enhances the coordination between Ministry of Panchayati Raj, Government of India and PRIs [17]. The central objective of this project is to ensure local area development and strengthen local self-governance by providing variety of services to its stakeholders. The stakeholders are elected representatives, Panchayat officials, citizens and other knowledge workers [18]. The Seventh Round Table Conference convened by Ministry of Panchayati Raj in 2004 had mentioned some major objectives in this regard that:

- It should be a decision support system (DSS) for the Panchayats

- A tool for improvement and internal management of Panchayats

- An efficient system for procurement

- A system for capacity building of elected representatives and bureaucrats

- A tool for enhancing transparency in the system It has formed a base for the conceptualization e-Panchayats as a MMP with seven major intents mentioned in the figure 1 . 


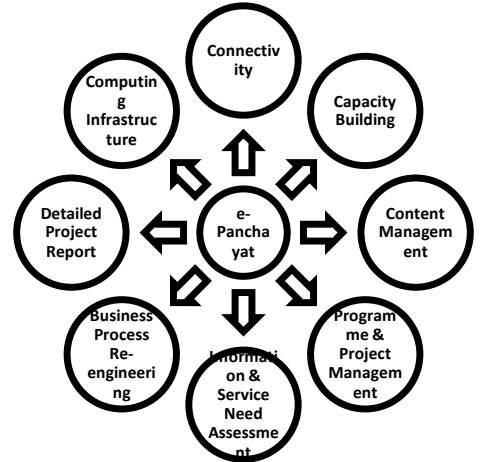

Fig 1: Major objectives of e-Panchayat MMP Source: www.epanchayat.gov.in

After conceptualization of e-Panchayat; a sequence of study phases were started viz information \& planning phase, information \& service needs assessment phase, process reengineering phase and detailed project report (DPR) preparation phase. Finally in 2009 e-Panchayat MMP was implemented by NIC with adequate capacity building mechanism and software operational manual.

\subsection{Services Delivered by e-Panchayat}

After finalization of project proposal and conceptualization of e-Panchayat, software development phase was initiated for the services intended to be delivered mentioned as under.

\subsubsection{Local Government Directory (LGD)}

The objective is to create and assign e-mail IDs to rural and urban local bodies along with management of their lists.

\subsubsection{Area Profiler}

This feature provides the socio-economic information, demographic details, details about public infrastructure and amenities etc.

\subsubsection{Plan Plus}

It facilitates PRIs in planning by assisting in data and process management associated with decentralized planning.

\subsubsection{PRIAsoft}

This application is focused towards management of financial accounts associated with various tiers of Panchayati Raj system.

\subsubsection{ActionSoft}

It facilitates PRIs in implementation and monitoring of various works or schemes.

\subsubsection{National Asset Directory}

It is an asset management systems which assist Panchayats in management of assets/ utilities created or owned by them.

\subsubsection{Service Plus}

The objective of this feature is to impart transparency in the system by managing grievances and their redressals.

\subsubsection{Training/Skill}

This module manages the demands of training or skills among various levels of PRIs and also accomplishes their conduct.

\subsubsection{Social Audit \& Meeting Management}

It manages the process of social audits conducted by Gram Sabha and their meetings.

\subsubsection{National Panchayat Portal}

It provides dynamic webpages to PRIs for content management and publishing.

\subsubsection{GIS Layer}

This module imparts spatial representation of some key reports like land records etc.

As it is a part of NeGP, therefore its regular monitoring will be conducted by NeGP apex committee which is headed by cabinet secretary, Government of India [19] [20][21].

\section{CONCLUSION}

Although India is having islands of success, but still there are numerous areas which are not explored or incorrectly explored. To upsurge the rural participation in developmental process a sound working mechanism has already been provided to the states by the Constitution of India. In the present world of science and technology it has become imperative for the each tier of planning to inculcate its use in the removal of burning problems of rural masses. Therefore, the ICT should be considered as an integral part of the policy. PRIs can be empowered by using ICT which results into successful implementation of poverty eradication programmes across the nation. Hence the poverty can be subsided significantly.

\section{REFERENCES}

[1] Patnaik, P. (2004). "On Changing Course", in India: An Agenda fo 2004. Social Scientist-Shamat, p. 8.

[2] Wikipedia. (2013, May 03). Demographics of India. Retrieved May 04, 2013, from The free encyclopedia: http://en.wikipedia.org/wiki/Demographics_of_India

[3] Wikipedia. (2013, November 27). Democracy in India. Retrieved December 06, 2013, from The encyclopedia: http://en.wikipedia.org/wiki/Democracy_in_India

[4] Bhattacharya, J. (2012). e-Gov 2.0. New Delhi: Tata McGraw Hill.

[5] Ministry of Home Affairs, G. o. (2011). Variation in Population since 1901. India, New Delhi: The Registrar General \& Census Commissioner.

[6] Dutt, G. (1998). Poverty in India and Indian States: An Update. The Indian Journal of Labour Economics, Vol. 41, No. 2, 41(2), 191-211.

[7] Puri, M. \&. (2011). India Economy. Mumbai: Himalya Publishing House.

[8] Alagh, Y. K. (1999). Panchayati Raj and Planning in India: Participatory Institutions and Rural Roads. Transport and Communication Bulletin for the Asia and the Pacific, pp. 1-27.

[9] Quoted in Alagh, Y. K. (1999). Panchayati Raj and Planning in India: Participatory Institutions and Rural Roads. Transport and Communication Bulletin for the Asia and the Pacific, pp.6.

[10] (2013). Annual Report 2012-13. Ministry of Rural Development Government of India

[11] (2013). Annual Report 2012-13. Ministry of Rural Development Government of India

[12] (May 2012). 30th Report of Standing Committee on Rural Development (2011-12). New Delhi: Ministry of Rural Development, Government of India. 
[13] Garai, A., \& Shadrach, B. (2006). Taking ICT to Every Indian Village: Opportunities and challenges. New Delhi: OneWorld South Asia.

[14] Parikh, T. S. (2009). Engineering Rural Development. Communications of The ACM, 54-63.

[15] Datar, M., Panikar, A., \& Farooqui, J. (2008). Emerging Trends in E-Government. In J. Bhattacharya, Critical Thinking in E-Governance (pp. 37-46). Hyderabad: International Congress of E-Government.

[16] Kumar, P., Kumar, D., \& Kumar, N. (2013). ICT in Local Self Governance: A Study of Rural India. International Journal of Computer Applications , 31-36.

[17] Wikipedia. (2013, March 29). E-Panchayat Mission Mode Project. Retrieved September 24, 2013, from An
Encyclopedia Website: http://en.wikipedia.org/wiki/EPanchayat_Mission_Mode_Project

[18] Verma, R. K., \& Kumari, A. (2010). e-Governance at Grassroots Level in South Asia: A Study of Citizencentric e-Panchayats in India. Asia-Pacific Journal of Rural Development, XX(I), 131-149.

[19] op.cit. Kumar, P., Kumar, D., \& Kumar, N. (2013).

[20] Misra, D., Hariharan, R., Dubey, A., Shrimali, M., \& Jian, D. (2012). Identifying common software needs of rural local governments in India. Journal of $\mathrm{E}$ Governance, 40-47.

[21] Raj, M. o. (2012). ePanchayat Mission Mode Project: A Status Report. New Delhi: Government of India. 